\title{
ФОРМИ НАЦІОНАЛЬНОЇ ДЕРЖАВНОСТІ УКРАЇНИ В 1917 - 1921 РОКИ
}

\section{НОВІЧЕНКО Андрій - доктор філософії, докторант Харківського національного університету внутрішніх справ}

DOI 10.32782/EP.2021.4.4

Украӥнсъкий народ у період часу з 1917 по 1921 роки переживав досить тяжкі, але значуші, для подальшого розвитку та «проивітання» держави та суспільства подій. Проблема державного будівниитва є сутmєвим дискусійним питанням історіі державотворення та правотворення за період часу з 1917 nо 1921 р.p. Націоналізачія завжди була $i$ є політичним інструментом. Начіоналізачія ставала революиійним гаслом досягнення процвітання держави в иілому, розглядалася як єдиний варіант відновлення зруйнованої війною (народними рухами) економіки, політики, соціальних аспектів життедіяльності суспільства, а також еволюиіонування від ідей політичної автономіӥ та федерачй до усвідомлення власной державної незалежності.

Подї, які відбувались з 1917 по 1921 р.p., $\epsilon$ загальноукраїнським явищем, при яких зароджувався та розвивався національний рух, створювались та проводили свою діяльність українсъкі органи влади, політичні партї та громадсъкі об’єднання, відроджувалась начіональна культура.

Така гостра політична боротьба за незалежність України в 1917 - 1921 р.р. залишила суттєвий «відбиток» не тільки в історіі України, а й у Світовій історї, що підбурило національну свідомість украӥнського народу на розвиток націоналізму та державотворення.

Ключові слова: начіоналізачія, украӥнсъкий народ, органи влади, державність, боротьба, незалежність.

\section{Постановка проблеми}

Упродовж багатьох століть український народ переживав як позитивні, так і негативні події становлення державотворення. Громадяни за допомогою національних рухів боролись за незалежність України, домагались від органів влади встановлення та дотримання своїх прав та свобод, відстоювали не тільки свої права, а й ще боролись за свою державу. Усі ці події, в кінцевому результаті, призвели до незалежності України.

32015 року по теперішній час в Україні відбувається реформування правоохоронних органів, запроваджуються нові підходи, форми, принципи тощо взаємин поліції та громадськості, а врахування історичного досвіду ставлення та розвитку діяльності органів влади при взаємодії з суспільством, з урахуванням національних традицій та українського менталітету, є запорукою успішної побудови партнерських взаємовідносин між поліцією та громадськістю.

\section{Стан дослідження проблеми}

Форми націоналізації державності неодноразово досліджувались вченими, серед яких є B.О. Боняк, М.I. Бортун, В.В. Землянська, П.М. Каркач, Т.О. Подковенко, М.І. Мичко, Т.О. Подковенко, Е.М. Попович, В.В. Сухонос, О.С. Козачук, І.М. Козьяков, Т.В. Корнякова, В.Г. Клочков та інші. Праці вчених є обширними та пізнавальними щодо форм націоналізації державності. Aле на теперішній час є потреба у додатковому дослідженні історико-правової 
характеристики форм націоналізації державності в період часу з 1917 по 1921 р.р. та виділення позитивних та негативних аспектів їх ставлення, що можна застосувати при запровадженні партнерських відносин між поліцією та громадськістю, діяльність яких спрямована на підвищення рівня протидії кримінальним правопорушенням та охороні правопорядку.

Мета дослідження полягає у дослідженні форм національної державності України у період часу з 1917 по 1921 роки. Аналіз взаємовідносин між органами влади тих часів та суспільства та історичних правових актів у період з 1917-1921 р.p.

\section{Наукова новизна дослідження}

Дослідження форм націоналізації державності України у період з 1917 по 1921 р.p. є значним для сучасної України. На теперішній час в Україні досить інтенсивно відбувається реформування органів виконавчої влади, у тому числі і правоохоронних органів. Оновлення діяльності поліції супроводжується впровадженням нових підходів взаємовідносин правоохоронних органів та громадськості, діяльність яких спрямована на підвищення рівня протидії кримінальним правопорушенням та забезпеченню правопорядку.

Аналізуючи досвід та нормативно-правові акти тих часів, можна виділити позитивні та негативні моменти взаємовідносин між органами влади та суспільства в усіх аспектах життєдіяльності у період з 1917 по 1921 р.p. Такий аналіз надає змогу не повторювати помилки попередників, 3 одного боку, а 3 іншого боку, враховувати позитивні сторони проведення партнерських взаємовідносин між органами влади та суспільством при впровадженні сучасних підходів у взаємини поліції та громадськості спрямованих на підвищення рівня протидії кримінальним правопорушенням та охороні правопорядку.

\section{Виклад основного матеріалу}

Період 1917 - 1921 років (Українська революція) має досить важливе значення для народу тому, що в цей період відбува- лось державотворення українських земель, що характеризувалось зміною політичної, військової, дипломатичної діяльності українських національних сил, спрямованих на створення самостійної держави.

Інтерпретація подій, що відбувались на території України, пов'язаних з революціями 1917 року і Громадянською війною, яка грунтується на підкресленні національних інтересів українського народу, які мали основоположне значення в історичному процесі того часу, сформувалася вже в 1920-і роки в українських емігрантських колах - у першу чергу, у роботах самих учасників революційних подій, які, природно, не могли бути неупередженими в оцінці самих подій і своєї ролі.

Радянська історіографія заперечувала існування Української революції, національно-визвольний рух і національно-державне будівництво на території України в 19171921 р.p. Події, що відбувались того часу, радянські історики розглядали у ракурсі складової частини Великої Жовтневої соціалістичної революції і Громадянської війни. Значна увага приділялась саме проблемам суспільно-політичного життя держави і різним формам формування української державності.

Сучасний український історик В. Солдатенко зазначає, що термін «Українська революція» 3'явився в політичних документах революційних років уже навесні 1917 року і в подальшому отримав широке поширення, у тому числі і в роботах українських політичних діячів, які зайнялися в еміграції «історичним аналізом спроби реалізації своїх планів і програм», такими є В. Винниченко, П. Христюк, М. Шаповал, Д. Дорошенко,I. Мазепа. Історик визнає, що, намагаючись протистояти офіційній радянській історіографії, українські історики і публіцисти в діаспорі далеко не завжди утримувалися на позиціях об'єктивності і все більше впадали в крайності, суб'єктивізм, що, природно, не множило науковості їх праць, робило їх вразливими і малопривабливими [1].

А.Ю.Іванова стверджувала, що словосполучення «Українська революція» залунало вже $з$ перших днів після повалення самодержавства, а «концепція (платформа) 


\section{Теорія, історія держави і права, конституційне право}

української революції народжувалася в подіях 1917 року та продовжувала оформлюватись надалі» [2, с. 41]. М. Шаповал, який друкувався під псевдонімом М. Сріблянський, у брошурі «3 біжучої хвилі» писав: «Як результат української революції - Українські Установчі Збори санкціонують лад, що установиться в революційному процесі» [3, с. 720]. У цей же час починає застосовувати термін «Українська революція» один 3 активних самостійників - Ф. Коломийченко, який закликав всіх свідомих діячів «до утворення Української Революції» та зазначав, що перед українством «залишається ще одна дорога, дорога Революції не «загальної», «не московської», але Революції Української» [4, c. 102-106].

Радянська історіографія, на відміну від емігрантських авторів, розглядала революцію в Росії як єдиний сформований більшовиками цілісний процес, характер якого визначався особливостями, які вона приймала в окремих регіонах, а виключно загальними закономірностями. Ті явища і події на Україні, які не вписувалися в загальноприйняту соціальну схему розвитку революційного процесу в Росії, характеризувалися як контрреволюційні і буржуазно-націоналістичні.

Вітчизняні історики умовно поділились на дві групи, де по різному трактують події, що відбувались у період часу з 1917 р. по 1921 р. Перша група дослідників усе ж таки називає визвольні змагання українського народу 1917-1921 р.р. - Українською революцією. До цієї групи відносяться праці таких учених, як Верстюка В.Ф., Пирога Г.Я., Солдатенкова В.Ф та ін. Друга група називає визвольні змагання українського народу - Української національно-демократичної революції 1917 - початку 1918 р. Усі наступні події вони виокремлюють та розглядають уже самостійно у частині державотворчої діяльності Гетьманату Павла Скоропадського, Директорії і ЗУНР.

«Українська революція» розглядається в роботах сучасних українських істориків як самобутне і самодостатне історичне явище, пов'язане, у першу чергу, зі спробами реалізації українською нацією свого права на політичне самовизначення, як явище, що характеризується тісним переплетенням соціальних і національних чинників і не зводиться до одного лише національного визволення. «Українська революція» як феномен була тісно пов' язана з Першою світовою війною, революційними змінами в Росії i, одночасно, з масштабними подіями, що відбувалися в Центральній і Східній Европі. Головною причиною революції вважається невирішене національне питання в поєднанні з глибоким загальнонаціональним невдоволенням і різними формами експлуатації. За своїм характером революція визначається як національно-демократична, органічно поєднувала рішення задач національного відродження і створення національної державності $з$ необхідністю глибоких соціальних змін в інтересах широких українських мас. Соціальною базою революції вважаються широкі верстви населення, перш за все селянство і національна інтелігенція [5].

«Українська революція» ставила собі за мету закріплення повномасштабних демократичних перетворень, а в довгостроковій перспективі - побудова демократичної республіки (за М. Грушевському - «народоправства»). Український національний рух ( «українство»), на думку прихильників цієї концепції, «влилося могутнім потоком у загальний процес демократичних перетворень» у колишній Російській імперії, здійснюючи вагомий внесок у незворотність розпочатої перебудови суспільства. Ідеалом національно-державних прагнень бачилася широка національно-територіальна автономія (протягом «самостійників», що вимагає негайного створення незалежної державності, на чолі з Н. Міхновським, скільки-небудь помітним впливом не користувалося) [1].

Згідно $з$ концепцією «Української революції», поштовхом до їі початку стала Аютнева (1917 р.) революція в Російській імперії, яка була направлена на подолання самодержавного режиму та встановлення демократії. На території України поглибився національновизвольний рух, який мав місце впродовж попередніх століть. Українська революція була спрямована на здобуття незалежності України за національне та соціальне визволення, встановлення демократії у державі, 
що супроводжувалось справедливим суспільним ладом.

У березні 1917 року відбулась ліквідація на території України органів царської адміністрації, перехід виконавчої влади до призначених Тимчасовим урядом губернським і повітовим комісарам, створення Української Центральної ради (УЦР), формування Рад робітничих і солдатських депутатів. У квітні 1917 р. відбувся Всеукраїнський національний з'їд, на якому було обрано новий склад і керівництво УЦР. У травні 1917 р. сформувались вимоги національно-територіальної автономії України, починається діяльність щодо формування української національної армії. Перші переговори представників УЦР $з$ Тимчасовим урядом, встановлення міжнародних контактів.

Згодом Українська Центральна Рада перетворилась у своєрідний український парламент. Головою Центральної Ради було обрано відомого українського історика, літературознавця, публіциста і громадського діяча Михайла Сергійовича Грушевського (1866-1934 р.p.).

Спочатку основною метою Центральної Ради було досягнення широкої автономії України в складі Російської держави. Це було продовженням федералістичної традиції, що бере початок у діяльності членів Кирило-Мефодіївського братства. Спроба досягти цієї мети через переговори з Тимчасовим урядом Росії провалилася. Російська влада відмовилася визнати Центральну Раду представником українського народу.

10 (23) червня 1917 р. Центральна Рада ухвалила I-й Універсал, який проголосив автономію України. Одночасно $з$ проголошенням Універсалу почалося створення національного уряду - Генерального секретаріату на чолі з Володимиром Кириловичем Винниченко (1880-1951 р.p.) [6].

3 (16) липня 1917 р. Центральна Рада проголосила II-й Універсал, який передбачав поповнення представниками національних меншин і перетворення його на єдиний вищий орган революційної демократії України [7].

7 (20) листопада 1917 р. Центральна Рада ухвалила III-й Універсал, у якому проголошувалося утворення Української Народної
Республіки (УНР) в межах 9-ти українських губерній. В Україні проголошувалися: ліквідація поміщицького землеволодіння, запровадження 8-годинного робочого дня, демократичні права і свободи, надання національним меншинам національно-персональної автономії, скасування смертної кари і т.П. [8].

До складу УНР були включені території, більшість населення яких складали українці: Київська, Волинська, Подільська, Херсонська, Чернігівська, Полтавська, Харківська, Катеринославська губернії i Північна Таврія. Заявлено про можливі територіальні претензії на частини Курської, Холмської, Воронезької та сусідніх губерній і областей з більшістю українського населення. Україна в односторонньому порядку вивела війська Південно-Західного і Румунського фронтів колишньої Російської армії з підпорядкування Ставці і об'єднує їх у самостійний Український фронт Дієвої армії УНР.

Значний вплив на державне будівництво України мали зовнішньо-політичні фактори. Жовтнева революція 1917 р. в Росії призвела до влади партію більшовиків на чолі з B.I. Леніним. У грудні 1917 р. радянська Росія оголосила війну УНР, змусивши керівництво Центральної Ради відмовитися від ідеї української автономії. Завдяки підтримці більшовиків, у Харкові було проголошено про встановлення радянського уряду УНР.

9 (22) січня 1918 р Центральна Рада проголосила IV-й Універсал, який проголошував УНР незалежною самостійною державою [9].

Нерішучість і непослідовність Центральної Ради у внутрішній і зовнішній політиці призвели до того, що навесні 1918 року Україна стала ареною складних політичних подій. Економічна і політична криза, яка охопила УНР навесні 1918 р., підштовхнула несоціалістичні сили України здійснити 29 квітня того ж року державний переворот. Очолив державний переворот почесний отаман Вільного козацьтва царський генерал Павло Петрович Скоропадський (18731945 р.р.). Було проголошено утворення Української держави на чолі 3 гетьманомП. Скоропадським. 


\section{Теорія, історія держави і права, конституційне право}

Гетьман Скоропадський встановив фактично диктаторську форму правління на Україні. На відміну від Центральної Ради, він цілеспрямовано прагнув створити потужну українську армію і централізований адміністративний апарат. За часів Гетьманату забезпечено економічне піднесення України, досягнуті помітні зрушення в галузі культури і освіти. Проводилась активна українізація державного апарату. Не закриваючи російські навчальні заклади, уряд паралельно створював українські університети і школи. Почала свою роботу Українська Академія Наук. Організована національна бібліотека України, прийнятий закон про обов'язкове вивчення української мови i лiтератури, історії та географії України у всіх школах.

Однак аграрна політика гетьмана Скоропадського була реакційною. Він захищав інтереси великих землевласників, поміщиків, а не селян. Поверталися землі колишнім власникам, для придушення опору селян, на село відправлялися каральні загони. Уряд Скоропадського також забезпечував безперебійне вивезення в Німеччину продовольства і сировини з України.

Влітку в країні великий розмах набрав страйковий рух. Страйк залізничників охопив близько 200 тисяч робітників і службовців [10, с. 287].

У процесі проведення народних страйків та інших протестів гетьману Скоропадському прийшлось дійти до компромісу 3 опозицією. Він намагався залучити в уряд представників української демократії. Переговори з ними вів Д. Дорошенко, однак тривалий час ці переговори були безрезультатними.

На початку серпня українські політичні партії та громадські організації на базі Українського національно-державного союзу створили Український національний союз. УНС проголосив своєю метою утворення суверенної демократичної Української держави парламентського типу, а тактичною лінією - створення єдиного національно-демократичного фронту [11, с. 213].

Уукінці жовтня 1918 р. Український національний союз з ініціативи партії хліборобів-демократів призначив на 17 листопада відкриття Національного конгресу, у порядку денному якого виявилися питання міжнародного становища України, легітимності влади гетьмана, економічної політики. Питання про дозвіл проведення конгресу розглянула Рада Міністрів. Голоси в уряді розділилися майже порівну: 7 міністрів (представники Національної спілки) голосували за проведення конгресу, 8 висловилися проти. Тоді 5 міністрів-представників УНС подали у відставку. Гетьман відправив у відставку весь уряд.

13 листопада в 1918 році на таємному засіданні Українського національного союзу розглядалося питання про збройний виступ проти влади П. Скоропадського. Було вирішено не поспішати з відновленням народної Республіки, а визначити оптимальну форму державного правління після перемоги повстання. Для керівництва виступом обрали тимчасовий верховний орган УНР - Директорію - у складі В. Винниченка (голова),С. Петлюри, Ф. Швеця, О. Андріївського,А. Макаренко.

Після розгрому під Мотовилівкою (18 листопада 1918 р.) найбільш боєздатних сил гетьмана питання про владу було вирішене: на початку грудня 1918 року армія УНР контролювала майже всю територію України. 14 грудня гетьман зрікся влади, яка перейшла до Директорії. Уже через півтора місяця УНР змушена була під ударами збройних формувань радянської Росії залишити українську столицю. 3 цього моменту для Директорії починався період політичної нестабільності, жорсткої боротьби за владу, безуспішних пошуків надійної зовнішньої та внутрішньої підтримки, нескінченних переїздів (Вінниця - Проскурів - Рівне - Станіслав - Кам'янець-Подільський), періодичних реорганізацій уряду (урядовий кабінет змінював свій склад шість разів, його очолювали В. Чеховський, С. Остапенко, Б. Мартос,I. Мазепа, В. Пилипенко) і кардинальних змін офіційної політичної лінії. Протягом свого існування Директорія поступово еволюціонувала до військової диктатури на чолі з С. Петлюрою.

Навіть володіючи диктаторською владою, С. Петлюра в тих умовах не міг керувати Україною. У різний час значні їі тери- 
торії знаходилися під владою англійських і французьких військ, білогвардійської армії генерала Денікіна, Червоної Армії, інших військових угруповань. Більше того, С. Петлюра не контролював повністю навіть власні збройні сили.

у 1920 р. С. Петлюра уклав договір 3 Польщею про спільну боротьбу з більшовиками і Радянською владою. За цим договором більшість земель Західної України мало відійти до Польщі. У результаті різко впав авторитет Петлюри серед українців, багато 3 яких у радянсько-польській війні 1920 р. підтримали Червону Армію. Восени 1920 р. залишки петлюрівських військ перейшли до Польщі, а сам Симон Петлюра був убитий у 1925 році.

3 кінця XVIII століття західноукраїнські землі входили до складу Австро - Угорщини. Після поразки Австро-Угорщини у Першій світовій війні почався іï розпад. Українські посли австрійського парламенту, депутати Галицького та Буковинського сеймів, лідери політичних партій та греко-католицького духовенства 18 жовтня 1918 р. утворили у Аьвові Українську Національну Раду. Нове представницьке утворення одразу поставило питання про об'єднання західноукраїнських земель в одне ціле і проголошення Української держави. У цих умовах, 13 листопада 1918 року була проголошена Західно - Українська народна республіка (ЗУНР) і створено їі уряд - Державний Секретаріат на чолі 3 Костянтином Левицьким. У той же день була створена Українська Галицька Армія. Одночасно відбувалося формування Польської держави, і поляки претендували на приєднання західноукраїнських земель до Польщі. Уряди ЗУНР і Директорії, намагаючись взаємно зміцнити позиції і реалізувати на практиці споконвічні мрії українців, 1 грудня 1918 р. у Фастові уклали попередню угоду про об'єднання ЗУНР (Галичина, Буковина, Закарпаття) і УНР (Наддніпрянська Україна). Керівники ЗУНР активно співпрацювали з УНР, і 22 січня 1919 року було прийнято угоду про входження ЗУНР до складу УНР [12].

Акт Злуки мав декларативний, символічний характер. Сторони, які об’єднувалися, не мали достатньої кількості державотвор- чих сил, щоб вистояти в складних умовах того часу. Армія ЗУНР не зуміла довго протистояти польській армії і влітку 1919 року припинила опір.

З 1920 р.із закінченням радянсько-польської війни і захопленням Червоною Армією Криму велика частина території України вже контролювалась Радянською владою.У Харкові, який був у руках більшовиків, було проголошено Українську соціалістичну радянську республіку (УРСР). Частина українських земель також увійшла до складу Польщі - Галичина і Волинь, Румунії - Північна Буковина і Бессарабія, Чехословаччини - Закарпаття.

У 1920 - 1921 р.p. розгорнулася боротьба Радянської влади із селянським рухом. Невдоволення селян викликала економічна політика Радянської держави. Ця політика пізніше отримала назву - «військового комунізму». Був заборонений вільний продаж зерна та інших продуктів селянського господарства. Здійснювалася продовольча розкладка - вилучення у селян зерна та інших продуктів. Більшовиками для цього застосовувалася збройна сила. У містах націоналізувалися не тільки великі, середні, а й дрібні підприємства. Запроваджувалася карткова система постачання як більш відповідна комуністичним принципам. Передбачалася ліквідація грошей і товарно-грошових відносин у цілому. Селянські повстання охопили величезні території країни. Найбільшим селянським виступом на Україні стали повстанці на чолі з Нестором Махном, а потім повстання йшли на південій Київщині. Народне невдоволення поставило більшовиків перед перспективою втрати влади. Тільки зміна економічної політики дозволила їм зменшити невдоволення.

Революція призвела до розпаду Російської імперії на ряд національних держав.У ході подій 1918-1921 р.p. у більшості з них встановилася Радянська влада. Усі національні компартії цих республік входили до складу Російської комуністичної партії більшовиків - РКП (б). Їх члени підкорялися рішенням керівних органів цієї правлячої в Росії партії. Таким чином, ці держави лише формально були незалежні. 


\section{Теорія, історія держави і права, конституційне право}

У період з 1917 року по 1921 рік Україна пережила різні форми націоналізації державності: Українська Народна Республіка за часи Центральної Ради, Українська держава - Гетьманат П. Скоропадського, Українська Народна Республіка за часи Директорії та Західноукраїнської Народної Республіки, але державну незалежність втримати не змогла

На думку історика В.Солдатенко, Українську революцію можна розділити на дві головні затяжні хвилі:

1) епоха Центральної ради (березень 1917 року - 29 квітня 1918 року);

2) перемога антигетьманського повстання під керівництвом Директорії УНР (14 грудня 1918 року) - кінець 1920 роки.

Між ними мав місце період контрреволюційного настання, що уособлюється гетьманом П. Скоропадським і його диктаторським режимом (29 квітня - 14 січень 1918 року) [62].

Періодизація Української революції 1917-1921 p.p. була сформована у середині 90-х p.p. ХХ ст.:

- березень 1917 - квітень 1918. Утворення та діяльність Української Центральної Ради, проголошення ії Універсалів;

- 29 квітня - 14 грудня 1918. Правління гетьмана Павла Скоропадського;

- грудень 1918 - листопад 1921. Встановлення влади Директорії УНР, розгортання та придушення масштабного повстанського pyxy [13].

\section{Висновки}

З 1917 по 1921 р.р. український народ переживав досить тяжкі часи, які супроводжувались і національними рухами, зміною органів влади, економічними кризами, переходу до різних форм правління тощо, але всі ці перетворення були спрямовані на встановлення незалежності держави.

Революція справила потужний мобілізаційний вплив на українські національні сили, сприяла консолідації нації, зростанню іiі етнічної і політичної самосвідомості. Вона остаточно ліквідувала статус, який мали українці у царській Росії, і змусила більшовиків піти на значні поступки українцям, за- безпечивши їм певні пільги в культурно-національному розвитку.

\section{Мiтература}

1. Солдатенко В. Ф. Українська революція 1917-1920 рр.: до з'ясування контурів та параметрів історичного феномену // доклад на международном научном коллоквиуме «Украина и Россия в 1917-1922 гг.: социальное и национальное в революции» (Институт Европы РАН, Центр украинистики и белорусистики МГУ, Институт всеобщей истории РАН, Институт славяноведения РАН, 13 ноября 2008 г.

2. Іванова А.Ю. Законодавчий процес і законодавча техніка в період Центральної Ради, Гетьманату П.П. Скоропадського та Директорії. Монографія / Анастасія Іванова. - К.: Наукова думка, 2011. - 223 с.

3. Український національно-визвольний рух. Березень - листопад 1917 року: Док. і матеріали. - К.: Видавництво Олени Теліги, 2003. - 1024 с.

4. Коломийченко Х. Революція в українському житті / Хведір Коломийченко // Шлях. - 1917. - № 5 - 6 (Липень - серпень). - С. 102-106.

5. Михайлюк А. В. «Украинская революция» или «русская революция» в Украине // Доклад на российско-украинской конференции историков «Украина и Россия: история и образ истории» (Москва, 3-5 апреля 2008 года)/

6. І Універсал Української Центральної Ради до українського народу, на Україні та по-за Україною сущого. URS: https:/uinp. gov.ua/istorychnyy-kalendar/cherven/23/1917pry y n a t t y a - pers ho go-universaluukrayinskoyi-centralnoyi-rady (дата звернення: 15.09.2021).

7. II Універсал Української Центральної Ради до українського народу, на Україні та по-за Україною сущого. URS: https:// www.jnsm.com.ua/h/0716P/ (дата звернення: 15.09.2021).

8. III Універсал Української Центральної Ради. URS: https://old.uinp.gov.ua/news/ tretii-universal-persha-respublika-do-100richchya-unr (дата звернення: 15.09.2021).

9. IV Універсал Української Центральної Ради. URS: https://uk.wikipedia.org/wiki/ $\%$ D0\%A7\%D0\%B 5\%D 1\%82\%D0\%B2\%D0\%B5 $\% \mathrm{D} 1 \% 80 \% \mathrm{D} 1 \% 82 \% \mathrm{D} 0 \% \mathrm{~B} 8 \% \mathrm{D} 0 \% \mathrm{~B} 9 \% \mathrm{D} 0 \% \mathrm{~A}$ $3 \% \mathrm{D} 0 \% \mathrm{BD} \% \mathrm{D} 1 \% 96 \% \mathrm{D} 0 \% \mathrm{~B} 2 \% \mathrm{D} 0 \% \overline{\mathrm{B}} 5 \% \mathrm{D} 1 \%$ $80 \% \mathrm{D} 1 \% 81 \% \mathrm{D} 0 \% \mathrm{~B} 0 \% \mathrm{D} 0 \% \mathrm{BB} \% \mathrm{D} 0 \% \mathrm{~A} 3 \% \mathrm{D} 0$ 
$\%$ BA\%D1\%80\%D0\%B0\%D1\%97\%D0\%BD\%D1 $\% 81 \% \mathrm{D} 1 \% 8 \mathrm{C} \% \mathrm{D} 0 \% \mathrm{BA} \% \mathrm{D} 0 \% \mathrm{BE} \% \mathrm{D} 1 \% 97 \% \mathrm{D}$ $0 \% \mathrm{~A} 6 \% \mathrm{D} 0 \% \mathrm{~B} 5 \% \mathrm{D} 0 \% \mathrm{BD} \% \mathrm{D} 1 \% 82 \% \mathrm{D} 1 \% 8 \overline{0} \% \mathrm{D}$ $0 \%$ B $0 \%$ D0\%BB $\%$ D $1 \% 8 \mathrm{C} \% \mathrm{D} 0 \% \mathrm{BD} \% \mathrm{D} 0 \% \mathrm{BE} \%$ D $1 \% 97 \% \mathrm{D} 0 \% \mathrm{~A} 0 \% \mathrm{D} 0 \% \mathrm{~B} 0 \% \mathrm{D} 0 \% \mathrm{~B} 4 \% \mathrm{D} 0 \% \mathrm{~B} 8$ (дата звернення: 15.09.2021).

10. Солдатенко В. Ф. Українська революція. Історичний нарис. - К., 1999. — С. 530.

11. Історія України / В. Ф. Верстюк,О. В. Гарань, О. І. Гуржій та ін., під ред.В. А. Смолія. - К., Альтернативи, 1997. $416 \mathrm{c}$.

12. Акт Злуки УНР і ЗУНР від 22.01.1919. URS: https://www.jnsm.com.ua/ h/0122N/\#\&gid=3\&pid=1 (дата звернення: 15.09.2021).

13. Українська революція 1917-21 [Електронний ресурс]. Режим доступу : : http://www.memory.gov.ua/page/ ukrainskarevolyutsiya-1917-21. (15.09.2021).

\section{FORMS OF NATIONAL STATEHOOD} OF UKRAINE IN 1917 - 1921

The Ukrainian people in the period from 1917 to 1921 experienced quite difficult, but significant, for the further development and "prosperity» of the state and society, events. The problem of state building is a significant debatable issue in the history of state formation and law-making for the period from 1917 to 1921. Nationalization has always been and is a political tool. Nationalization has always been and is a political tool. Nationalization became a revolutionary slogan for the prosperity of the state as a whole, seen as the only option for restoring the war-torn economy, politics, social aspects of society, as well as evolving from the ideas of political autonomy and federation to self-realization.

The events that took place from 1917 to 1921 are an all-Ukrainian phenomenon in which the national movement was born and developed, Ukrainian authorities, political parties and public associations were created and carried out, and national culture was revived.

Such a sharp political struggle for the independence of Ukraine in 1917 - 1921. left a significant «imprint» not only in the history of Ukraine but also in world history, which incited the national consciousness of the Ukrainian people to the development of nationalism and statehood.

Keywords: nationalization, Ukrainian people, authorities, statehood, struggle, independence. 